\title{
An anhanguerian pterodactyloid mandible from the lower Valanginian of Northern Germany, and the German record of Cretaceous pterosaurs
}

Pascal Abel, Jahn J. Hornung, Benjamin P. Kear, and Sven Sachs

Acta Palaeontologica Polonica 66 (3), 2021: s005-s012 doi:https://doi.org/10.4202/app.00818.2020

The record of Cretaceous pterosaur remains from Germany is sparse. The material recovered to date includes the fragmentary holotypes of Targaryendraco wiedenrothi and Ctenochasma roemeri, as well as a few isolated pterodactyloid teeth and some indeterminate skeletal elements, together with a plaster cast of a large Purbeckopus manus imprint. Here, we report the discovery of a pterodactyloid pterosaur mandible from lower Valanginian strata of the Stadthagen Formation in the Lower Saxony Basin of Northern Germany. Based on the size and spacing of its alveoli, this fossil is attributable to the cosmopolitan Early Cretaceous pteranodontoid clade Anhangueria. Moreover, it represents the first and only known pterosaur from the Valanginian of Germany and is one of only a handful Valanganian pterosaur occurrences presently recognized worldwide. In addition to the approximately coeval Coloborhynchus clavirostris from the Hastings Bed Group of southern England, the Stadthagen Formation pterosaur mandible is among the stratigraphically oldest identifiable anhanguerians.

Key words: Pterosauria, Pterodactyloidea, Anhangueria, Cretaceous, Stadthagen Formation, Lower Saxony.

Pascal Abel [pascal.abe194@web.de], Senckenberg Centre for Human Evolution and Palaeoenvironment, Eberhard-Karls- University Tübingen, Sigwartstraße 28, 72076 Tübingen, Germany. Jahn J. Hornung [jahn.hornung@yahoo.de ], Niedersächsisches Landesmuseum Hannover, Willy-Brandt-Allee 5, 30169 Hannover, Germany. Benjamin P. Kear [benjamin.kear@em.uu.se], Museum of Evolution, Uppsala University, Norbyvägen 22, 75236 Uppsala, Sweden. Sven Sachs [sachs.pal@gmail.com], Naturkunde-Museum Bielefeld, Abteilung Geowissenschaften, Adenauerplatz 2, 33602 Bielefeld, Germany. 
This is an open-access article distributed under the terms of the Creative Commons

Attribution License (for details please see creativecommons.org), which permits unrestricted use, distribution, and reproduction in any medium, provided the original author and source are credited.

Faril Full text $(654.1 \mathrm{kB})$ 